\title{
Spirit And Figure of Ratu Kalinyamat in Contemporary Batik
}

\author{
Muh Fakhrihun Na'am¹, Deni Setiawan ${ }^{2}$, Wulansari Prasetyaningtyas ${ }^{3}$ \\ $\left\{\right.$ fakhri.artworker@mail.unnes.ac.id ${ }^{1}$, deni.setiawan@mail.unnes.ac.id ${ }^{2}$,wulan_sari@mail.unnes.ac.id $\left.{ }^{3}\right\}$ \\ Department of Family Welfare, Faculty of Engineering, UNNES, Semarang, Indonesia ${ }^{13}$ \\ Department of Primary Education, Faculty of Education, UNNES, Semarang, Indonesia ${ }^{2}$
}

\begin{abstract}
Creativity in creating and producing the contemporary batik originated from traditional arts, either its form, ideas for creation, or historical reference of the local figuration of Ratu Kalinyamat, is an effort to promote and to popularize batik by making innovation on the decorative designs, to the common people and to the industrial community of Nusantara batik. The batik artists are the main character in the promotion of traditional batik publicly. The community is a group of artists who play the role to create the trend of decorative motifs in order that the popularity of the traditional batiks wrapped in contemporary crafts can be meaningful things to the batik fanatics. The personal and social interaction within the artists cycles when creating batik originated from the traditional artworks and the values of traditional arts on the contemporary batik works, it is interesting to be scrutinized as sociological analysis or arts. In addition to viewing the social correlation between batik artists and the artworks lovers, it also is aimed at understanding the meaning of the traditional arts ideas originated from Ratu Kalinyamat created through the form of contemporary batik. Thus, we find out that the ideas coming from the traditional arts are the main foundation of the contemporary batik creation.
\end{abstract}

Keywords: Ratu Kalinyamat; Batik; traditional arts

\section{Introduction}

Ratu Kalinyamat has track record that is very important to Jepara people, figure of maritime city pioneer and the history of her popularity in the past as part of the Nusantara wealth, that is properly made motivation. The phenomenal female figure that can be role model and has positive impact on local and national interests. Viewing the potential, the artists have special space and functions in terms of artworks creation inspiration searching and innovation. The artists as the arts creator should prioritize the ability of creavity actualized into the innovative fine artworks, so they create esthetical experience on their lovers.

Actions and rites are the integral parts of the figures and the authorities' cultural activities in terms of governing. In addition to the invasion to Malaka against the Portuguese imperialism, Ratu Kalinyamat in advance conducted meditation and soaking ritual that leaves the trace that still is existing, i.e. in Donorojo Jepara. Rituals are the activity that become the heart of the batik works creation. Ritual is interpreted as a journey in which there is an illustration of the activities during the rites connoted as a traditional ceremony. So are the daily activities that inspire the creation of batik works. 
Various social phenomena arising among the society are caused by the mistaken paradigms, symbolism distortion, wrong direction, poor historic knowledge that can inspire the modern women, i.e. Ratu Kaliyamat's invasion to Malaka to expel the Portugese is not widely known yet. This phenomenon aroused the inspiration on the creators (batik artists) to visualize it into the meaningful batik works. This inspiration is not a simple thing. The spirit of resistance shown by Ratu Kalinyamat is the important substance as the inspiration to the artwork's creation. The inspiration originated from the story of Ratu Kalinyamat is part of the revelation that has many phenomenological contents from all the things that happened to Ratu Kalinyamat as the key inspiration to the creation of the contemporary batik works. The presentation of the revelation is expressed into the decorative motifs applied to batik by putting character of Ratu Kalinyamat onto a unique and original work. Those values are related to religiosity, patriotism, and local wisdom, wrapped in the contemporary style of arts.

The word "contemporary" can be interpreted into what happens recently, the contemporary arts become the newly created artistic product. Arts, however, develop internally as a history, and contemporary arts constitute artistic products manufactured in a specific production structure that has never been seen before. Context of "modern" shows a style and period, not merely anew manufactured artworks; the character of contemporary arts show something more than just an art today (Danto, 1997: 10). The term contemporary art does not have firm meaning and boundary as the contemporary fine arts are viewed as the existing fine arts and its durability is not tested yet. (Danto, 1997: 11).

The term "contemporary fine arts" is not applicable to all the created artworks, including the artworks created in the past categorized into product of modern fine arts (Gibbons, 2007, xiii). Contemporary fine arts are product of cultural-historic tradition, confronting with Western in the modern and economic change era, including information technology that has tighten the world toward a global culture and is driven by the interaction between each condition above (Turner, 1994: xiii-xiv). The term "contemporary fine arts" can connote what just or recently happens. In relation with arts, it comprises a period of forty or more years, and it is related to two generations of artists (Gibbons, 2007, xiii).

The making of contemporary batik speaks more about the artists' personal expression, while the batik manufacture is affiliated more with trend, economic, and batik industry issues. Based on Sue Jenkyn Jones' opinion, the categorization of artists can be analogized with the type of batik they create, i.e.: batik artists with high-skilled techniques (for special needs) (Jones, 2002:25). Common batiks can be categorized into the mass products, with batik for special needs is produced in limited number. The batik in this study is still being designed and will be put into "batik for limited production" category.

\section{Methodology}

The study is the qualitative research using the qualitative data, i.e. historic observation on Ratu Kalinyamat'spirit. In order to find the social context that the batik artists are in and the manufactured contemporary batik, as well as the meaning of the inspiration for creation and the origin of traditional arts, I use sociologic paradigm of arts. The main study of the art sociology is social relationship issues in the place where the artworks are created. The power of sociology of art hitherto is the development of institutional study methodologies and practices of cultural production. In addition, cultural analysis is regarded as part of the wider social and historic frame (Kuper and Kuper, 2008:41-42). To analyze the decorative motifs of 
batik, I used several other approaches: design studies and contemporary fine arts theory, that becomes analysis foundation and tool. Design approach is applied to analyze the shapes and colors, referring to the elements of design and their correlation with the contemporary fine arts.

The explanation about contemporary batik inspired by figure of Ratu Kalinyamat shows its correlation with the existence of contemporary fine arts. Analysis of batik decorative motifs constitutes a part of the works analysis. Work's analysis aims to explain the work in relation with its visual appearance. Work's analysis is curator's job, in this case, however, as an intellectual artist, in addition to visualizing; I also should be able to make analysis to meet my analytical responsibility.

\section{Result and Discussion}

Howard S. Becker classifies artists into four categories: integrated professionals, maverick artists, folk artists, dan naive artists (Becker, 1982:227). The contemporary batik artists can be seen in two groups of artists, i.e. Integrated professionals technical and social skills and conceptual tools needed to find it easier for him to create the artworks, because he understands and gets used to adapting to public convention. Historically, this group could create the recognizable and understandable works, the commonness and code-relevant values can be found in the created works. Whereas, there is not continuously existing world of arts without a help of artists/people who create unique products (Becker, 1982: 229-230).

Another group is maverick's artist, the artists who resist against the social convention of general artworks creation. The artists joined the group give important symbol in case of the resistance against convention of artworks creation. The creation that rebels against the general convention of batik decorative motifs, in this area the artists play role as the people who give the room to the contemporary batik to develop as a process of two-way communication between the artists (artworks creator) and the arts lovers. The artists' resistance gives space for the development of new variations and enriches the visual motifs of batik Nusantara, instead.

To understand the things related to the world of arts, Richard Wollheim takes three approaches: realism, where the quality of esthetics is absolute regardless the human's view; objectivism, constitutes absolute value, too, nevertheless it depends on human experience in general; relativism, where there is not absolute value, it varies and depends on the human's different experiences (Wollheim, 1980). The character of art, as explained by Wollheim, is one of the most ambiguous things of all the human traditional concerns. Art is defined as the tool to express or to communicate emotions and ideas, a way to explore and to appreciate the formal elements on behalf of them, and as mimesis or representation. Definition making or art shows the existence of artistic products (contemporary batik) as a media to express and to express a thought to somebody else. This shows the artists' role as communicator and mediator that bridges the artistic products with the arts lovers.

Batik, where its creation inspiration is originated from the figure of Ratu Kalinyamat, constitutes one of the contemporary craft products. The fact that shows the existence of the crafts in Indonesia, particularly in Java, contains three important things: myth, ritual, and symbol. The three things reflect the contents of spirit, soul, and psychology of culture of nation, implying the achievement of esthetic quality of Indonesian craft art, adjusted to its period (Gustami, 2007:303). The three things discussed by SP. Gustami constitutes the realization of entity on batik as the contemporary craft products. One of the contemporary 
characterizes in the inspiration craft works creation is presenting various traditional prosperity and local resources in Indonesia, from the usage of batik, weaved fabric, knitted fabric, and any other traditional fabrics. The creation inspired by history, myths, folktales, and Indonesian comic plays special part as a learnt lesson and the propagation of the information about the Nusantara prosperity publicly. The batik artists play key role to propagation of information about the Nusantara prosperity.

The ability to create artworks is correlated with three faculties, which are different in each human. Gustami said, every human body has three faculties of feelings that play key role in the knowledge processing and discovery about artworks creation. Batik as the contemporary craft products constitutes the output of processing and discovery of knowledge that is used to meet the batik designers' and consumers' needs. The faculties Gustami means are faculty of faith, faculty of rationale, and faculty of feeling (Gustami, 2007, 312). Faculties of faith and rationale are representation of enthusiasm to create and the ability to create analytically, critically, and comprehensively. On the processing rationale and feeling, to take the emergence of various options due to the sensitivity of sense, ethics, esthetics, and personality in terms of receiving various phenomena into consideration. It is the management of the three faculties creating various styles of contemporary batik created by the batik artists.

Every craft work (including the creation of contemporary batik) goes through the phases of creation process, initiating from the concept hunt to the final process. The execution the contemporary batik exhibition in several places and time can be reference to create the sustainable and high-quality artworks. The reflection (intuition gaining) conducted by the batik artists to create batik in new concepts constitutes small part of a series of creation proses. The creation process of a contemporary batik can happen either intuitively or through scientific method planned carefully, analytically, and systematically. Gustami splits the 3 (three) phases into 6 steps of craft work creation process (Gustami, 2007, 330-332), as follows.

\section{Exploration phase, comprises;}

a) Soul wandering, field observation, and reference and information sources exploration to determine the theme. The initial phase conducted is the efforts to find various sources and references as basic of contemporary batik creation. The data collection to find the sources of contemporary batik concept becomes the initial study to create the decorative designs of batik with particular references. On Ratu Kalinyamat batik, the style is created through observation of spirit and figure based on a few references. The contemporary batik is the batik artists' creation inspired by figure of Ratu Kalinyamat.

b) The exploration of theoretical framework, visual origins and reference can be used as analysis matter so I can get the significant solution. The origins exploration aims to collect the data concerning the needs of contemporary batik creation, such as: determining the material/fabric, designing and determining the decorative motifs, determining the technical thing, creation method, and some supporting aspects (philosophical, sociocultural, and inspiration of creation). The sources exploration is the process aiming to solve the challenge and to determine the measures that should be taken.

\section{Creation phase, comprises:}

a) Step three: idea expression and verbal analysis. It is expressed into two dimensional shapes by considering the aspects of material, technical process, method, construction, ergonomically, safety, convenience, harmony, balance, esthetics, style, philosophy, message, meaning, also social, economic, and cultural functions, as well as its future 
chance. The step comprises contemporary batik design sketching and planning. The design comprises projective images, alternative material selection, decorative motifs and accessories planning, including technical actions to create the contemporary batik consistent with the determined concept.

b) Step four, visualization of ideas from sketch to prototype form. Prototype or mockup making aims to find the final visual of the created artworks. The contemporary batik prototype making was conducted to minimize the mistake made during the working process, to determine the creation technique and process, to find the complexity of the design, and to determine the esthetics on the batik creation.

\section{Realization phase, comprises:}

a) Step five, realization phase based on the prototype regarded as perfect, from the initial process to finishing. This phase is the realization phase of the contemporary batik referring to the determined design. The batik creation was conducted consecutively, starting from designing, sewing the basic design, adding detail accessories, stuffing, to the final stage. This step is relatively more easily taken because it is carried out based on the design determined in advance

b) Step six, assessment or evaluation. This is the testing step of the created work by taking some aspects into consideration. The assessment or evaluation aims to control of the quality of the product, to assess the congruity between the design and the final product, and to make revision based upon the evaluation.

The six steps of artworks creation explained by Gustami are taken by a group of batik artists based on Howard S. Becker's version, i.e.: integrated professionals and mavericks' artist. The batik artists play key roles in the existence and development of craft works. Based on the artists' activities to popularize contemporary batik, they can be classified as follows.

\section{Integrated Professionals}

The batik artists participated actively in creating the new type of contemporary crafts by considering the particular esthetics. Technical knowledge and conceptual tool owned by the batik artists allow this group to participate to maintain and to popularize contemporary batik publicly. Referring personal function of arts, the artists play role as a creator with their ideas, imaginations, and thoughts that are realized and then create an artwork. The artist is placed as the people who create a batik trend, meet the lifestyle need, and satisfy the public needs of esthetics. The artwork reflects the artist's thinking, emotional, and psychological character.

The contemporary batik adopted the thought of trendy that refers to the exclusive fashion, has high quality materials, produced in limited amount, and the change happens between three months to a year. Integrated professionals group play role to create competition to create new and special products on contemporary batik, as a measure to give wider chance to the development of Nusantara batik decorative designs.

\section{Mavericks Artist}

The artists included in this group give alternative solutions to the public needs to enjoy the beauty of Nusantara batik. Contemporary batik creation is conducted not to follow the batik common convention. In this area the artists play the role as those who give chance to the development of one type of decorative motifs as a process of the artist's expression to the arts lovers as consumers. Nanang Ganda Prawira makes classification concerning the creator and the lovers of these artworks in three groups (Prawira, 2000). The first group is the one who 
maintain the tradition and keep up the old rules and custom. Such traditional society obviously has traditional arts inherited by their ancestors. Generally, the products of such traditional arts belong collectively to a society, are based on the old rules that are sustained. Those rules are originated from the old tradition generally related to the spiritual needs.

The second group is the one who accommodate the old and the new cultures. This kind of society tends to develop by creating the modifications (cultural transformation) and uses the base of the old traditions (inherited by their ancestors). The old culture, thus, is maintained by not resisting the influence of the developing new culture. The elements of the new culture coming from outside (as new things) are selected and taken to develop their culture. In this case, the we can see the renewal action without leaving their basic old tradition. The third group is a group of people who always want the new values. The restoration is conducted continuously by disregarding the old values. The old things are considered old-fashioned and ancient, so the tendency to develop the culture by putting the new elements is the way they do it. In arts, the restoration measures are in line with the creativity development that always wants novelty. This will always lead the arts to the change every time, either its form or its contents.

The three groups of the arts products creators and lovers can be regarded as the important parts in the development and the existence of contemporary batik. The decision to choose the creation and loving one of types of artworks, either maintaining the deep-rooted tradition, combining the long-standing tradition with the new one, or creating a work inspired by the new tradition is strongly affected by the interests and influence on the management of three faculties of feelings as explained by Gustami. Characteristics of maintaining the old tradition, how the artists play their role to keep the originality that becomes sign of a tradition and culture among certain society. What happens is contemporary batik creation referring to folktales, legend, mythology, and the society belief represented into an artwork product.

Evaluation of an artwork can be conducted through observation and research because those values have actually been directly applied to every artwork that the artists create. The appearance of artwork wrapped in various media delivers specific messages. First, the value of the appearance that bears the art objects or artifacts consists of value of shape and value of structure. Second, the value of contents such as the values of knowledge (cognition), the value of sense, intuition or human subconsciousness, the value of ideas, the value of message or value of life, such as: moral value, social value, and religious value. Third, the value of expression to show the existence of value of personal talent, skill value, and the value of the medium he uses. Those three values are integrated into an entity in an artwork appearance (Prawira, 2000).

Some contemporary concepts regarding the contemporary batik Ratu Kalinyamat are the followings.

\section{Locality Concept and Theme of Tradition}

The creation of Ratu Kalinyamat contemporary batik is originated from the local references, they are: traditional fabrics, the theme that represents the cultural prosperity and tradition that adopt the phenomenon concerning social tradition into an artwork with locality character and reflects the similar era in which the product was created. The main reference of the creation is originated from the cultural prosperity and local social phenomena, response to spirit and figure of Ratu Kalinyamat that developed in the past amongst the Jepara people's life. The creation of variants of contemporary crafts is inspired by locality context, gives room for the traditional view to be applied in modern form. Contemporary batik, thus, constitutes representation of the treasures of early tradition, contains esthetics of local culture, a view that 
is introduced in presentation concept of current esthetics by elaborating the local potentials of Indonesian people.

Products of contemporary batik in ideas area accommodate several types of ideology, concepts, philosophy originated from tradition and culture reflecting the state of somebody or a group of people. Contemporary crafts often take the new rules into effect regarding the way of thinking, someone's freedom to create, to make imitations, to create new products, as well as to develop particular idioms. One of the ideas in contemporary fine arts is to observe the products of tradition which constitutes the accommodation of historical culture originated from the previous era. This sign is shown in the creation concept of Ratu Kalinyamat batik, most of which is inspired by the old-fashioned thinking (based on Ratu Kalinyamat saga), represented into contemporary batik.

The fusion of historic cultures can be interpreted as the forms of the artists' creation pattern disciplinary to introduce the story of Nusantara tradition using the contemporary batik fabrics publicly. In addition to ideas, the traditional decorative motifs are used as indicator of concept of tradition. Locality can be interpreted as traditional batik style created by responding to the sources of figure of Ratu Kalinyamat. The character of combining the old and new tradition constitutes the measure to make innovation on the cultural products of tradition, such as: mixing the decorative designs of batik fabrics and putting composition into the contemporary batik to be product of art (exhibition stuff). The people's activity to create an artwork inspired by new tradition is the key indication of the emergence of the contemporary styles. The creation of contemporary batik is originated not only from the local and traditional culture, but also presents the ideas and creation with new inspirations.

\section{Pluralism Concept}

Contemporary fine arts include what is called new idiom. The new idiom "products of contemporary crafts" in Jepara is viewed not only from the usage of multiplural creation material and concepts, including the additional function as exhibition stuff (presentation tool), and resistance against the works creation in general. The idiom change in the product of contemporary crafts can be caused by several things, such as: social change among the society because of internal and external influence; response to the political, social, and cultural issues, as well as developmental pressure in the crafting industry as the inspiration. As stated by Soedarso Sp, the noticeable characteristics in Indonesian contemporary fine arts is the rise of social and political themes, the emergence of anti-formalism tendency, the prominence of pluralism with local elements, and the regrowth of the realism traditional and representative tendency. The transformation of paradigm goes in line with the awareness of bringing the exhibition events to international scope by introducing local issues and Indonesian traditional culture that will attract the international community (Soedarso SP., 2006:188-190).

The plural character in the creation concept becomes the style reference, therefore there are double identity in the created contemporary craft products. We can see it from the limitless usage of the materials on the products of contemporary crafts, by combining various concepts. In addition, there a variety of colors, mixture of decorative motifs and accessories originated from several regions, including mixture of traditional and modern decorative motifs. Products of contemporary crafts are the artists' improvisation, as the mode of creativity and response to the emergence of various styles of fine arts with combination of colors, media, and decorative motifs originated from several regions in Indonesia. The contemporary craft styles in Jepara constitute modification of some identities a part of which modify the original form (combining the traditional and modern decorative motifs) and improvisation of functions, so it creates more dynamic new types. 
Development character of contemporary fine arts field on the craft products can be viewed from the most obvious indication, i.e. varied concept of thinking, the mixture of creation media, the more varied accessories used, and the change of products functions into ornaments. For instance, the form and the addition of new function to batik as part of products for show. The combination of a variety of culture constitutes the character of contemporary fine arts, as plural character and have many references. Products of contemporary crafts as cultural products with various decorative motifs in form of symbols on the material (the use of batik fabrics, weaved fabrics, knitted fabrics, and webbings) speaks about the social issues and the face of culture that exist amongst the people. The symbols that boil down to the abstract ideas constitute accumulation of a few kinds of philosophical meanings preserved and introduced as parts of artworks communication.

\section{Parody Concept}

The development of contemporary fine arts occurring after the modern era is often associated with postmodern era. Not all contemporary fine arts, however, are postmodern arts. Postmodernism describes the movements originated from and that react to the modernism tendency. The specific tendencies of modernism that are often mentioned are the purity of the shape, arts for arts, authenticity, universality and originality. The assumptions regarding modernism get many attacks, such as through a parody that is so-called ironic quotes, pastiche or recycle. As stated by Linda Hutcheon, either through parody or another type of reproduction, concept of originality as something rare, single, and precious is questioned again (Hutcheon, 2004:147-148).

Plurality is viewed not only as combination of various references of creation and decorative motifs of batik, but it also contains ideology of resistance against modernism ideas, reflections of social situation and condition of a society, including introducing the sociocultural phenomena into the artworks, where the modernism ideas in the batik speak about the functions conventionally, subsequently due to people's pressure in postmodernism era, the functions are no longer main elements of batik. When mass product (industry) like batik, it usually is produced into an artwork in form of exclusive batik. Here the parodic ideas starts emerging, on batik works that transform into paintings. The people are provided with the show of the emergence of the end of art era, which constitutes the sign of freedom to use various media and ideas to make and to create artworks.

The styles of contemporary batik develop in line with political, social, and cultural situation among the Jepara people. Products of arts become one of cultural elements that play key role in the cultural structure of a community. The difference of cultural character creates products of arts in various shapes and media with specific characteristics. Batik creation activities under the effective social code constitutes a type of social interactions between the artists and the people through the products of artworks.

\section{Conclusion}

Every batik artist has interests in and purpose on every artwork he creates. The purpose can be knowledge, trend creation, and economic interest in various batik styles. The style of the created contemporary Ratu Kalinyamat batik constitutes expression of the artist's ideas and thoughts which will cause various reactions when presented publicly. The emerging reactions are the consequence of the artwork's presentation. It can be love, hate, anger, and 
rejection to the assessment based on particular convention. When there is resistance against one type of contemporary batik, it means that the artist has different thinking from the effective social convention.

The conveyance of appearance value, content value, and expression value of a type of batik by disregarding the effective social convention is the batik artist's effort to express his ideas and views. Those ideas and views can be resistance against the social conventions, criticisms and suggestions, or in order to create new variation of batik contemporary style. The emergence of batik as product of contemporary craft has strong relation with the existence of concepts on the contemporary fine artworks in general. The emergence of contemporary batik is the indication of Western existence in the ideas of local works creation. Contemporary batik is created not anymore referred to functions conventionally, but it has new idiom as artifact for exhibition purpose. The expression style of crafts artists that changes from functional into presentative works happens in it. Batik that changes into exhibited stuff, mockup of functional stuff, and parodies in traditional decorative motifs, is the type of development of traditional crafts into contemporary ones.

\section{References}

[1] Barnard, Malcolm. Fashion sebagai Komunikasi: Cara Mengkomunikasikan Identitas Sosial, Seksual, Kelas, dan Gender. Jepara: Penerbit Jalasutra, Cetakan ke-2, 2009.

[2] Bayu, Krisna dkk, 2011. Ensiklopedi Raja-Raja Jawa dari Kalingga hingga Kesultanan Jepara. Jepara: Araska.

[3] Becker, Howard S. Art Worlds. Berkeley and Los Angeles, California: University of California, Ltd., 1982.

[4] Danto, Arthur C. After the End of Art. Princenton: Princenton University Press, 1997.

[5] Djajadiningrat, Hoesein. 1983. Tinjauan Kritis Tentang Sejarah Banten. Terjemahan KITLV dan LIPI. Jakarta: Penerbit Djambatan.

[6] Gibbons, Joan. Contemporary Art and Memory: Images of Recollection and Remembrance. New York: I.B.Tauris \& Co Ltd., 2007.

[7] Gustami, SP. 2007. Butir-Butir Mutiara Estetika Timur: Ide Dasar Penciptaan Seni Kriya Indonesia. Jepara: Prasista.

[8] Gustami, SP. Butir-butir Mutiara Estetika Timur: Ide Dasar Penciptaan Seni Kriya Indonesia. Jepara: Prasista, 2007.

[9] Hauser, Arnold. The Social History of Art. Chicago: The Chicago University Press, 1982. Hayati, Chusnul. 2007. Ratu Kalinyamat Biografi Tokoh Wanita Abad XVI Dari Jepara. Pemkab Jepara Puslit Sosbud Lemlit Undip Semarang: Penerbit Jeda.

[10] Hutcheon, Linda. Politik Posmodernime, dialihbahasakan oleh Apri Danarto. Jepara: Penerbit Jendela, 2004.

[11] Jones, Sue Jenkyn. Fashion Designs. London: Laurence King Publishing, 2002.

[12] Kuper, Adam dan Jessica Kuper. Ensiklopedi Ilmu-ilmu Sosial. Jakarta: RajaGrafindo Persada, edisi 2, 2008.

[13] Morris, Desmond. Manwatching: A Field Guide to Human Behavior. New York: Harry N. Abrams, Inc., Publishers., 1977.

[14] Na'am, M. F, dan H. Arif. 2014. Journal The Need To Preserve and Promote Rejomulyo Batik Designs as Semarang's Local Products.9(22): 16277-16292.

[15] Na'am, M. F. 2018. Kearifan Lokal Motif Batik Semarang Sebagai Ide Dasar Model Kreatif Desain Kaus Digital Printing. Journal teknobuga.1 (6): 2085-4056.

[16] Na'am, M. F., 2015. Ornament In Mantingan Mosque And Tomb: Analysis Of Form, Function, And Symbolic Meaning. Proceeding Of 1 St Unnes International Conferenc On Research Innovation \& Commercialization For The Better Life 2015: 296-302.

[17] Na'am, M. F. 2018. Kearifan Lokal Motif Batik Semarang Sebagai Ide Dasar Model Kreatif Desain Kaus Digital Printing. TEKNOBUGA. 6 (1) : 19. 
[18] Prawira, Nanang Ganda. "Kriya dan Rekahias Baduy: Bentuk, Fungsi, Motif, Simbol dan Makna: Kriya dan Rekahias Masyarakat Baduy di Desa Kanekes, Kecamatan Leuwidamar, Kabupaten Lebak", dalam Jurnal Seni Rupa dan Desain, Vol. 1, (1), (Agustus, 2000, Bandung: STISI).

[19] Ratna, Nyoman Kutha. 2010. Metode Penelitian Kajian Budaya dan Ilmu Sosial Humaniora Pada Umumnya. Jepara: Pustaka Pelajar.

[20] Rizali, Nanang. "Kecenderungan Pasar dan Perkembangan Mode Sebagai Alternatif Pendekatan dalam Perancangan Tekstil Cetak" dalam Jurnal Seni Rupa dan Desain, Vol. 1, (1), (Agustus, 2000, Bandung: STISI).

[21] Rohidi, Tjetjep Rohendi. 2011. Metode Penelitian Seni. Semarang: Cipta Prima Nusantara.

[22] SP, Soedarso. Trilogi Seni, Penciptaan Eksistensi dan Kegunaan Seni. Jepara: Badan Penerbit ISI Jepara, 2006.

[23] Sudibyo, Z.H. 1980. Babad Tanah Jawi. Jakarta: Proyek Penerbitan Buku Sastra Indonesia dan Daerah Depdikbud.

[24] Sunardi, ST. 2012. Vodka dan Birahi Seorang "Nabi”. Jepara: Jalasutra.

[25] Turner, Caroline. "Internationalism and Regionalism: Paradoxes of Identity" dalam Turner, Caroline (Ed.). Tradition and Changes: Contemporary Art of Asia and the Pacific. University of Queensland Press, 1994.

[26] Wollheim, Richard. Art and its objects. Cambridge University Press, 1980. 